\title{
Overwintering Honey Bee Colonies in Northern Climates $^{1}$
}

\author{
James D. Ellis and Katherine Hammons²
}

\section{Introduction}

One of the many challenges beekeepers face is minimizing honey bee colony losses during winter. This can be especially challenging to beekeepers in extreme northerly climates (such as Alaska and northern Canada). Special preparations must be made during the fall to ensure that colonies survive the winter months with minimal loss. Of course, there will always be some colony loss, but with good management, losses often can be reduced to below $10 \%$. Bees naturally prepare for winter on their own, but they may need the assistance of a beekeeper to ensure survival through winters in extremely cold climates.

\section{Fall Preparation}

Preparation of the colony for winter must begin in late summer or early fall. In northern climates, preparation usually starts in August/September, though it may begin earlier depending on the location. Beekeepers must ensure that there are enough food stores for the entire winter and that the colony is healthy and strong. One of the leading causes of colony death during the winter is lack of food. Generally, there should be about 90 pounds of honey reserves for a colony in the North, since bees will not be able to forage in the winter. If there is not enough honey stored in the supers for the winter after the removal of surplus honey by the beekeeper, the hives can be supplemented with a mixture of high fructose heavy corn syrup or, better yet, sugar syrup ( 2 parts sucrose sugar: 1 part water by volume) in the fall.
Bees will store the syrup as a substitute "honey" for use throughout the winter. Colonies that have enough honey or stored sugar syrup to survive winter will pass the "lift" test. To conduct a lift test, attempt to lift the colony with one hand using the handle on the back of the bottommost super. If the hive is difficult to rock forward with one hand, then it likely has enough food reserves to survive winter. If the hive is easy to lift, then it probably needs more food.

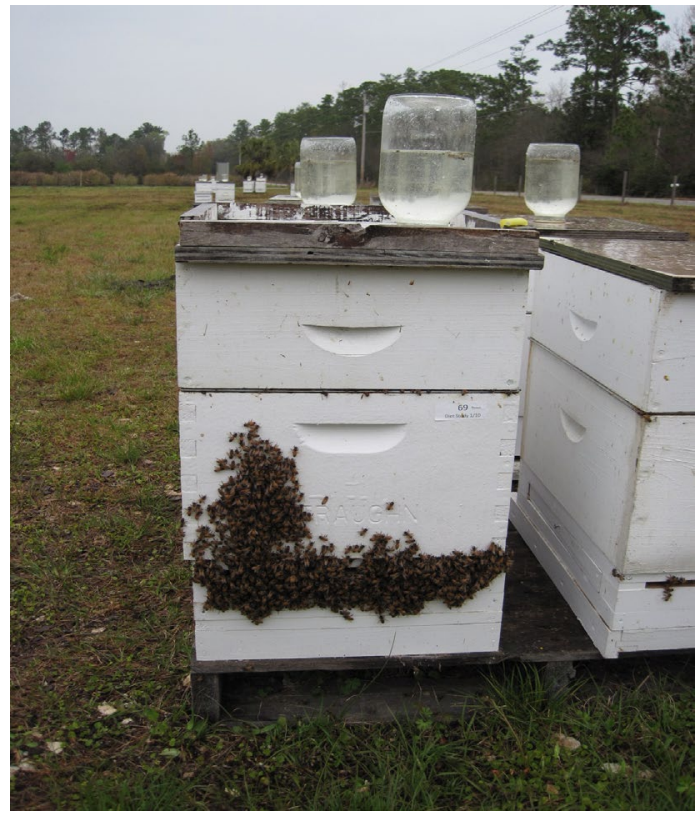

Figure 1. Hives getting supplemental sugar syrup through top feeders. Other feeders also can be used to deliver sugar or high fructose corn syrup to colonies.

Credits: University of Florida

1. This document is ENY-161, one of a series of the Entomology and Nematology Department, UF/IFAS Extension. Original publication date September 2013. Visit the EDIS website at http://edis.ifas.ufl.edu.

2. James D. Ellis, assistant professor; and Katherine Hammons, former graduate student; Department of Entomology and Nematology; UF/IFAS Extension, Gainesville, FL 32611 
Some colonies may be located in areas that experience a fall nectar flow from goldenrod, aster or other fall-blooming plants. This flow may allow the bees to store enough reserves, but honey production should be monitored carefully by the beekeeper during this time. The best way to learn about local honey flows in your area is to contact a horticulturalist at a local county or state extension center or mentor with an experienced beekeeper from your immediate area. An alternative to supplementing with syrup is to supplement weak colonies with extra honey from stronger colonies. Care must be taken if this path is chosen because diseases may be spread from one colony to another through infected honey or frames.

Beekeepers must also ensure that the honey stores are properly located within the hive. Brood should be located in the bottom hive body (brood box, or deep super), and surrounded by cells filled with pollen. The pollen-filled cells, in turn, should be surrounded by cells filled with capped honey. A typical colony will naturally create this brood/pollen/honey pattern.

Most races of bees cover stored pollen with honey, often sealing the honey, making it hard to measure the amount of pollen stored within a colony. Late summer and early fall bees can be fed abundant protein and store many food reserves in their body to feed to late winter and early spring brood.

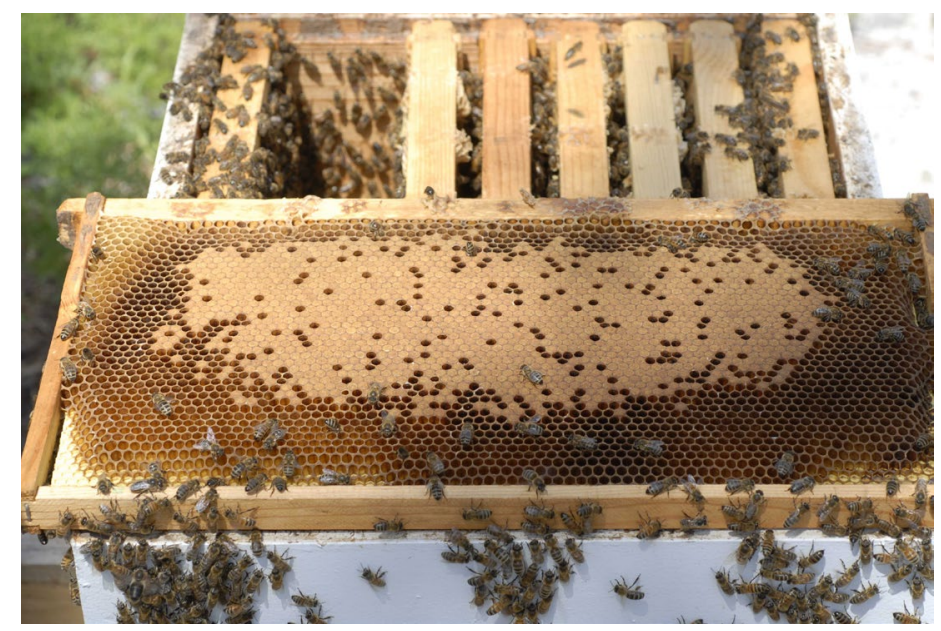

Figure 2. A good brood pattern shows capped brood in the center, with pollen and honey surrounding the brood.

Credits: University of Florida

Bees will cluster around the queen in the bottom brood box as temperatures drop. The center of the cluster is maintained at approximately $95^{\circ} \mathrm{F}$ while brood is present. As winter progresses, the cluster of bees will move up through the colony as a unit, slowly eating through their honey stores. It is important that food stores are available above and beside the cluster. Because wintering clusters tend to

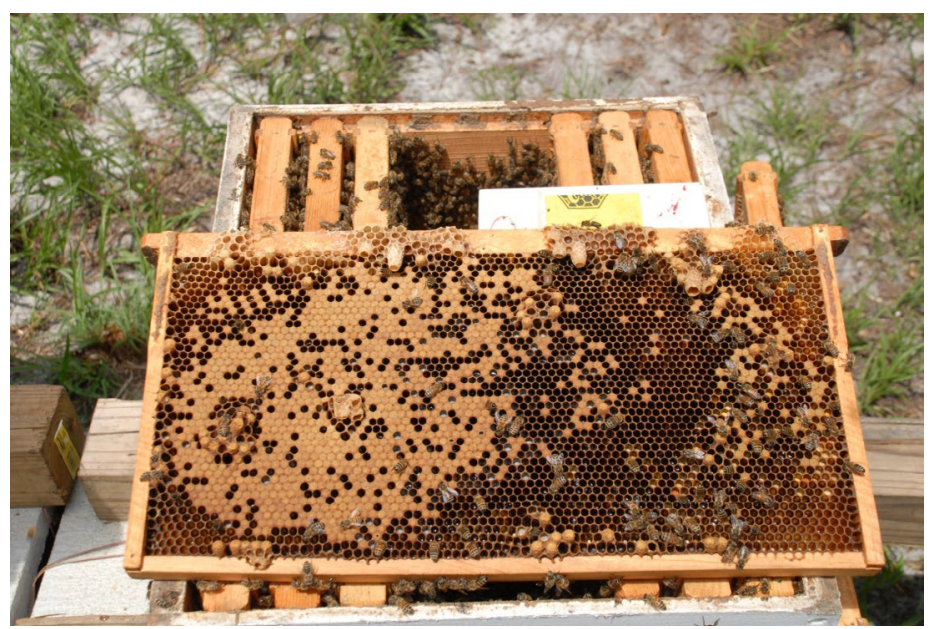

Figure 3. A spotty brood pattern, as seen here, suggests a failing or missing queen or a colony with potentially bad health. Colonies with brood patterns like this in early fall often do not survive winter. Credits: University of Florida

move up in the nest, remove any queen excluders that are still on the hives after the last nectar flow. Otherwise, the queen can be trapped below the excluder as the cluster migrates upward throughout winter.

\section{Colony Health}

Colonies must be strong and healthy and have a productive queen when entering winter. This will discourage disease and ensure there will be enough bees in the cluster to create and retain heat. Weak colonies may need to be combined with stronger ones during late summer/early fall to increase chances of survival. A healthy colony consisting of 25,000 to 30,000 bees is an adequate size for overwintering success. Colonies with fewer than 15,000 bees are not likely to survive freezing temperatures, though they may survive in locations with milder winters. Re-queening in early fall ensures a healthy productive queen for the winter. Checking the health of the adults and the brood in the fall is important because having many bees clustered together in a tight space allows the proliferation of pests and pathogens.

The most common health problems during or leading into winter are rodents, Varroa mites (Varroa destructor), tracheal mites (Acarapis woodi), and Nosema (Nosema apis and N. ceranae). Varroa mites weaken colonies in late summer and can lead to weak colonies heading into fall and winter, leaving the wintering bees heavily infested. Because winter is a mainly broodless time, the phoretic mites feed on the bees' hemolymph all winter, reducing their vitality and shortening their lifespan. Under these circumstances secondary viral infections will often develop and emphasize the problem. Consequently, one must monitor Varroa populations and treat if necessary. Nosema and tracheal 
mites tend to be a bigger problem during the winter months.

Rodents can cause a big problem in the winter by entering hives looking for heat and shelter. Rodents can destroy comb and consume honey, leaving little for the bees. Entrance reducers or wired mouse guards can be placed at hive entrances as simple and easy defenses against nest invaders.

See the following resources for more information on the control of various threats:

- Bears and bear fences:

"Florida Bears and Beekeeping" http://edis.ifas.ufl.edu/ aa133

- Varroa mites:

"Varroa Mite, Varroa destructor Anderson and Trueman (Arachnida: Acari:Varroidae," http://edis.ifas.ufl.edu/in855

episode 4 of the Video Field Guide to Beekeeping on Varroa mites http://entnemdept.ifas.ufl.edu/honeybee/extension/ VarroaMites.shtml

- Tracheal mites:

"Honey Bee Tracheal Mite, Acarapis woodi (Rennie) (Arachnida: Acari: Tarsonemidae" http://edis.ifas.ufl.edu/ in 329

episode 1 of the Video Field Guide to Beekeeping on Tracheal mites http://entnemdept.ifas.ufl.edu/honeybee/ extension/TrachaelMites.shtml

\section{- Nosema:}

episode 2 of the Video Field Guide to Beekeeping on Nosema http://entnemdept.ifas.ufl.edu/honeybee/extension/Nosema.shtml

\section{Hive Location}

Ensuring proper hive location is extremely important during winter months, especially in northern climates. Hives must be sheltered from the wind, but still have adequate air flow to discourage the build up of moisture within the hive. Early morning sun helps heat the hives during the day. In locations that regularly freeze, consider using one of the many top-insulation systems to prevent heat loss from the cluster as it moves to the top of the food stores, but make sure there is adequate ventilation. This may be done with an upper entrance, an auger hole in the side of the top box, or a ventilation rim. Care must be taken to ensure proper air flow.

Beekeepers in the far northern states and Canada may wrap colonies to reduce wind infiltration and to warm the hive on sunny days. For more information on how to wrap a colony for overwintering, please see the following two instructional posters from the University of Minnesota Bee Lab http://www.beelab.umn.edu/prod/groups/cfans/@ pub/@cfans/@bees/documents/asset/cfans_asset_317473. pdf and http://www.beelab.umn.edu/prod/groups/cfans/@ pub/@cfans/@bees/documents/asset/cfans_asset_317473. pdf. Some beekeepers keep hives in indoor wintering facilities, though they must be temperature controlled so that the bees do not attempt to forage. Hive entrances must be open on both the bottom upper hive entrance for ventilation.

\section{Winter Management}

The best thing a beekeeper can do once winter begins is to manipulate hives as little as possible. While quick checks are possible at lower temperatures, inspections should be brief and conducted only on warmer days $\left(>50^{\circ} \mathrm{F}\right)$ if absolutely necessary. The colonies will begin to rear brood when they sense the days are getting longer and rapidly expand the brood nest when pollen becomes available.

\section{Summary}

With the proper preparation, colonies can be overwintered in cold climates successfully. Colonies must be queenright and healthy, and must have plenty of honey stored by the bees so that it is accessible to them during the winter months. The hive must be in a sunny location, out of the wind, and wrapped if necessary. Colonies are far more likely to survive winter if these preparations are done properly. Even when all appropriate preparations are taken, some colonies still may not survive. Colony death is a regular part of beekeeping. However, winter colony losses can be minimized with adequate preparation.

\section{References}

Connor, D. M. and L. J. Connor. 2013. Honey Bee Biology and Beekeeping, Wicwas Press, Kalamazoo, MI. 360 pp.

Delaplane, K. S. 2006. Honey Bees and Beekeeping: A Year in the Life of an Apiary, $3^{\text {rd }}$ Edition. The Georgia Center for Continuing Education, Athens, GA. 108pp.

University of Minnesota Bee Lab. http://beelab.umn.edu/ $(6 / 5 / 2013)$ 